\title{
Does the Heparin Infusion Decrease the Risk of Catheter Related Thrombosis in Neonates with Central Venous Catheters?
}

\section{Dr Muhammad Umar Sahi ${ }^{1}$ and Dr Taha Haroon Rasul ${ }^{1}$}

\author{
${ }^{1}$ Paediatric Trainee Registrar. ST6 Paediatric Intensive Care \\ Unit, Leicester Royal Infirmary
}

${ }^{2}$ Paediatric Trainee ST2. Leicester Royal Infirmary

\section{Clinical Scenario}

A preterm newborn baby needs a peripherally inserted central venous catheter (PICVC) for the administration of parenteral nutrition (PN), intravenous (IV) fluids and medications. Echocardiogram is performed on this baby to ascertain the presence of PDA. Echocardiogram shows an incidental finding of inferior vena cava (IVC) thrombosis that is partially blocking the IVC. Here the question arises whether administration of continuous infusion of heparin through the central venous catheters including the umbilical venous catheters (UVC) or peripherally (percutaneous) inserted central venous catheters, commonly referred as long lines can reduce the incidence of catheter related thrombosis in neonates.

\section{*Corresponding author}

Dr Muhammad Umar Sahi, Paediatric trainee registrar. ST6 Paediatric Intensive Care Unit, Leicester Royal Infirmary, Infirmary Square Leicester, LE1 5WW. United Kingdom, E-mail: dr.umarsahi@gmail.com

Submitted: 15 Apr 2020; Accepted: 23 Apr 2020; Published: 01 May 2020

\section{Structured Clinical Question}

In term and preterm neonates does continuous heparin infusion as compared to no heparin infused through the central venous catheters decrease the risk of catheter related thrombosis?

\section{Searches}

MEDLINE was searched via the Pubmed interface from 19962019 using: Heparin AND central AND venous AND (catheter OR catheters). Search was limited to English articles. The search retrieved 520 articles, full text assessed for 11 articles and 5 included. The Cochrane database of systematic reviews was searched and found no additional study.

\section{Summary}

Table 1 Results of the relevant literature search:

\begin{tabular}{|c|c|c|c|c|c|}
\hline Citation & Study group & Study type & Outcome & Key result & Comments \\
\hline Pita Birch et al (2010) & $\begin{array}{l}\text { Neonates }(\mathrm{n}=210) \\
\text { receiving TPN } \\
\text { through a long line. } \\
\text { Heparin group, } \mathrm{n}=102 \\
\text { received heparin } \\
\text { mixed in TPN. } \\
\text { Control group, } \mathrm{n}=108 \\
\text { had no heparin in TPN }\end{array}$ & $\begin{array}{c}\text { Single centre RCT } \\
\text { (Level1) }\end{array}$ & $\begin{array}{l}\text { Primary outcome } \\
\text { Episodes of catheter } \\
\text { related sepsis (CRS) } \\
\text { Secondary outcomes } \\
\text { Catheter occlusion } \\
\text { Safety of heparin }\end{array}$ & $\begin{array}{c}\text { There was statistically } \\
\text { significant reduction } \\
\text { in CRS in heparin } \\
\text { group. } \\
\mathrm{RR}=57 ; 95 \% \mathrm{CI} \\
(0.32-0.98), \mathrm{p}=0.04 \\
\\
\text { There were no } \\
\text { statistically significant } \\
\text { differences for } \\
\text { catheter obstruction } \\
(\mathrm{RR}=1.76 ; 95 \% \mathrm{CI} \\
0.48-6.56, \mathrm{p} 0.42) \\
\text { or IVH progression } \\
\text { in heparin group } \\
(\mathrm{RR}=0.3 ; 95 \% \mathrm{CI} \\
0.07-1.24 ; \mathrm{p} .011)\end{array}$ & $\begin{array}{c}\text { Dose of heparin was } \\
0.5 \mathrm{IU} / \mathrm{ml} \text { of TPN. } \\
\text { Peripherally inserted } \\
\text { central venous } \\
\text { catheters studied. }\end{array}$ \\
\hline
\end{tabular}




\begin{tabular}{|c|c|c|c|c|c|}
\hline F Kamala et al. (2002) & $\begin{array}{l}\text { Newborn babies were } \\
\text { randomized to receive } \\
\text { TPN containing either } \\
\text { heparin }(n=35) \text { or no } \\
\text { heparin }(n=31) .\end{array}$ & $\begin{array}{l}\text { Single centre RCT } \\
\text { (Level1) }\end{array}$ & $\begin{array}{l}\text { Primary outcome } \\
\text { Catheter occlusion } \\
\text { Secondary outcomes } \\
\text { Safety of heparin }\end{array}$ & $\begin{array}{c}\text { Heparin group had } \\
14.3 \% \text { blocked } \\
\text { catheters and no } \\
\text { heparin group had } \\
22.6 \% \text {. Difference } \\
\text { is statistically not } \\
\text { significant. } \\
\mathrm{RR}=0.6 ; 95 \% \mathrm{CI} \\
(0.2-1.08), \mathrm{p}=0.4 \\
\\
\text { There was no } \\
\text { difference in platelet } \\
\text { count, APTT, bilirubin } \\
\text { or triglyceride level or } \\
\text { worsening of IVH in } \\
\text { heparin group. }\end{array}$ & $\begin{array}{l}\text { Dose of heparin was } \\
1 \mathrm{IU} / \mathrm{ml} \text { of TPN. } \\
\text { Due to confounding } \\
\text { factors almost half } \\
\text { of catheters were } \\
\text { prematurely removed } \\
\text { in each group limiting } \\
\text { the firm conclusions } \\
\text { to be drawn from the } \\
\text { results. Also the study } \\
\text { sample was too small } \\
\text { as perceived by the } \\
\text { author. }\end{array}$ \\
\hline $\begin{array}{l}\text { Bracho-Blanchet et al } \\
\qquad(2010)\end{array}$ & $\begin{array}{c}\text { Children }<18 \text { years } \\
\text { of age including } 12 \\
\text { newborn babies. One } \\
\text { arm } \mathrm{n}=38 \text { received } \\
\text { heparin mixed in } \\
\text { TPN/ IV fluids. Other } \\
\text { arm } \mathrm{n}=38 \text { had no } \\
\text { heparin in IV fluids/ } \\
\text { TPN }\end{array}$ & $\begin{array}{l}\text { Single centre RCT } \\
\text { (Level1) }\end{array}$ & $\begin{array}{l}\text { Effect of heparin on } \\
\text { thrombus formation } \\
\text { and occlusion of } \\
\text { catheters. } \\
\text { Safety of heparin }\end{array}$ & $\begin{array}{c}\text { Heparin arm showed } \\
\text { thrombus in } 7.8 \%, \\
\text { control arm had } 63 \% \text {. } \\
\text { RR=20; } 95 \% \text { CI }(5.1- \\
77.2), \mathrm{p}<0.001 \\
\text { Heparin arm showed } \\
\text { occlusion in } 5.3 \% \text {, } \\
\text { control arm } 47.8 \% \\
\mathrm{RR}=2.3 ; 95 \% \mathrm{CI} \\
(1.6-3.38), \mathrm{p}<0.001 \\
\\
\text { There was no } \\
\text { presence of bleeding } \\
\text { or prolonged clotting } \\
\text { times during the use } \\
\text { of heparin. }\end{array}$ & $\begin{array}{c}\text { Dose of heparin was } \\
2 \text { IU/ml of IV fluids/ } \\
\text { TPN. } \\
\text { Thrombosis was } \\
\text { detected by visual } \\
\text { inspection upon } \\
\text { withdrawal of catheter. } \\
\text { Most the double } \\
\text { lumen catheters were } \\
\text { inserted in subclavian } \\
\text { or internal jugular } \\
\text { veins. }\end{array}$ \\
\hline PS Shah et al (2007) & $\begin{array}{l}\text { Total of } 201 \text { neonates } \\
\text { were enrolled. } \\
\text { Experiment group } \\
(\mathrm{n}=100) \text { received } \\
\text { heparin into the } \\
\text { CVC through } \\
\text { separate lumen and } \\
\text { the controlled group } \\
(\mathrm{n}=101) \text { received } \\
\text { placebo }\end{array}$ & $\begin{array}{l}\text { Multicentre } \\
\text { RCT (Level1) }\end{array}$ & $\begin{array}{l}\text { Incidence of occlusion } \\
\text { and thrombosis } \\
\text { in heparin versus } \\
\text { placebo group } \\
\\
\text { Safety of heparin } \\
\text { infusion. }\end{array}$ & $\begin{array}{c}\text { The incidence of } \\
\text { catheter occlusion was } \\
\text { significantly lower in } \\
\text { heparin group. } \\
\mathrm{RR}=20,95 \% \mathrm{CI} \\
(0.09-0.42), \mathrm{p}=0.001 \\
\text { There was no } \\
\text { statistically significant } \\
\text { difference in } \\
\text { thrombosis incidence } \\
\text { in two groups. (20\% } \\
\text { in heparin versus } 21 \% \\
\text { in placebo group) } \\
\text { No adverse effects } \\
\text { attributable to heparin } \\
\text { seen including } \\
\text { IVH, significant } \\
\text { thrombocytopenia or } \\
\text { death }\end{array}$ & $\begin{array}{l}\text { Dose of heparin was } \\
0.5 \mathrm{IU} / \mathrm{kg} / \text { hour. After } \\
\text { contacting the author } \\
\text { the concentration of } \\
\text { heparin infusion was } \\
\text { confirmed as } 1 \text { units/ } \\
\text { ml of heparin in } 10 \% \\
\text { Dextrose. Author used } \\
\text { Doppler USS within } \\
72 \text { hours of removal of } \\
\text { catheter to diagnose } \\
\text { the CVC related } \\
\text { thrombosis. }\end{array}$ \\
\hline
\end{tabular}




\begin{tabular}{|c|c|c|c|c|c|}
\hline S Uslu et al (2010) & $\begin{array}{l}239 \text { Newborn babies } \\
\text { were randomized } \\
\text { to receive heparin } \\
(\mathrm{n}=118) \text { through a } \\
\text { separate lumen into } \\
\text { the CVC or no heparin } \\
(\mathrm{n}=121)\end{array}$ & $\begin{array}{c}\text { Single centre RCT } \\
\text { (Level1) }\end{array}$ & $\begin{array}{l}\text { Catheter related } \\
\text { thrombosis and } \\
\text { occlusion. } \\
\text { Safety of heparin }\end{array}$ & $\begin{array}{l}\text { The incidence of } \\
\text { catheter occlusion } \\
\text { in heparin group is } \\
\text { significantly low. } \\
\mathrm{R}=3.44 ; 95 \% \mathrm{CI} \\
\text { (1.92- } 6.44), \mathrm{p}=0.0001 \\
\text { The incidence of } \\
\text { thrombosis is low in } \\
\text { heparin group but is } \\
\text { not significant. (1.7\% } \\
\text { versus } 4.1 \%) \\
\text { No heparin related } \\
\text { adverse effects } \\
\text { seen including } \\
\text { thrombocytopenia, } \\
\text { prolonged aPTT, IVH, } \\
\text { arrhythmia and death. }\end{array}$ & $\begin{array}{c}\text { Dose of heparin was } \\
0.5 \mathrm{IU} / \mathrm{kg} / \text { hour along } \\
\text { with TPN. } \\
\text { Author used visual } \\
\text { inspection to detect } \\
\text { the thrombus along } \\
\text { the length of CVC } \\
\text { after its removal. }\end{array}$ \\
\hline
\end{tabular}

RCT, randomized controlled trial; IV, intravenous; TPN, total parentral nutrition; IU, international units; IVH, intraventricular haemorrhage; USS, ultrasound scan

\section{Discussion}

Neonates treated in neonatal intensive care units (NICUs) usually needs a protracted venous access for the administration of parenteral nutrition, fluids and medications. Peripherally inserted percutaneous central venous catheters (PICVCs) and umbilical venous catheters (UVCs) are the two commonly used methods to gain a dedicated venous access in neonates. Although PICVC is considered the preferred route of venous access in many NICU settings it has complications including mechanical problems (like kinking of tube, dislodgement and extravasation), occlusion, catheter related sepsis and thrombosis $[1,2]$. There has been a strong concordance between intravenous catheter occlusion and thrombus formation. Found that occlusion of CVCs has greater than $80 \%$ of concordance for detecting thrombosis [5]. Studies have revealed that CVC also correlates with the intravascular fibrin sleeve formation around the catheter which may be considered a step towards thrombus formation [6]. Attempts have been made to prevent thrombus formation in indwelling CVCs by using heparin infusion into the catheters. The anticoagulative properties of heparin and its postulated antifibrin sleeve formation effects are thought to prevent CVC related thrombus and the catheter occlusion [7]. Evaluated the prophylactic use of heparin to prevent the catheter related thrombus formation in adults. In the meta-analysis of 7 randomized controlled trials it concluded that prophylactic heparin significantly decreases CVC related thrombosis by $57 \%(\mathrm{RR}, 0.43 ; 95 \% \mathrm{CI} ; 0.23,0.78)$ [8]. Results remained significant after exclusion of 1 trial that assessed heparin bonded catheters (RR; $0.44 ; 95 \% \mathrm{CI} ; 0.22,0.87$ ), and concluded heparin dosed at $3 \mathrm{U} / \mathrm{ml}$ of TPN was effective in reducing CVC related thrombosis in adults however lower doses may not be.

Trialled safety and efficacy of heparin to prevent thrombosis and occlusion of neonatal CVCs $[9,10,11]$. The dose used was 0.5-2.0 $\mathrm{IU} / \mathrm{ml}$ of heparin mixed in TPN or intravenous (IV) fluids. BrachoBlanchet used the highest dose of $2.0 \mathrm{IU} / \mathrm{ml}$ of heparin mixed in TPN/IV fluids. There was no significant difference in the incidence of thrombosis or catheter occlusion in any of these 3 studies even with the highest dose of heparin. Used low equivalent dose of $0.5 \mathrm{IU} / \mathrm{kg} /$ hour of heparin infused in the CVC through a separate lumen $[12,13]$. The incidence of catheter occlusion, patency and catheter related thrombosis was found to be significantly reduced in these studies. Shah used Doppler ultrasound scan to detect CVC related thrombosis and found only $1 \%$ less incidence of thrombosis in heparin group and Uslu used visual detection of thrombosis at the tip of catheter after its removal and found more than twice the number of catheters with thrombosis in no heparin group. For an average weight of $2.5 \mathrm{~kg}$ neonate who is on $150 \mathrm{ml} / \mathrm{kg} /$ day of total PN/IV fluids the babies who received 2 IU of heparin mixed with PN/IV fluids were given 25 times higher dose as compared to the study groups who had heparin infusion given through a separate lumen into the CVC. Effects of heparin to prevent CVC related occlusion or thrombosis was significantly higher in latter group though none of the groups showed heparin related adverse effects. These results warrant conducting larger studies with higher doses of heparin infused through a separate lumen into the CVC confirm if these effects are real.

\section{Clinical Bottomline}

Heparin infused through a separate lumen into the central venous catheter may reduce the incidence of thrombosis and catheter occlusion in neonates with central venous catheter as compared to the babies with no heparin or the heparin mixed with the PN/IV fluids. (Grade A)

\section{References}

1. Goutail-Flaud MF, Sfez M, Berg A, Laguenie G, Couturier C, et al. (1991) Central venous catheter-related complications in newborns and infants: a 587-case survey 26: 645-650.

2. Cartwright DW (2004) Central venous lines in neonates: a study of 2186 catheters Archives of Disease in Childhood - Fetal and Neonatal Edition 89: F504-F508.

3. Saracco P, Bagna R, Gentilomo C, Magarotto M, Viano A, et al. (2016) Neonatal Working Group of Registro Italiano Trombosi Infantili (RITI). Clinical Data of Neonatal Systemic Thrombosis 171: 60-6.e1.

4. Cheri M John, Christian Harkensee (2005) Thrombolytic agents for arterial and venous thromboses in neonates Cochrane Systematic Review.

5. Bracho-Blanchet E, Cortés-Sauza J, Dávila-Pérez R, Lezama- 
Del Valle P, Villalobos-Alfaro C, et al. (2010) Usefulness of intravenous heparin to prevent thrombosis of central venous catheter in children 78: 423-429.

6. Krzywda EA (1998) Central venous access--catheters, technology, and physiology. Medsurg Nurs 7: 132-139.

7. Di Costanzo J, Sastre B, Choux R, Reynier JP, Noirclerc M, et al. (1984) Experimental approach to prevention of catheterrelated central venous thrombosis. JPEN J Parenter Enteral Nutr. 1984 May-Jun 8: 293-297.

8. AG Randolph, Deborah J Cook, Calle A Gonzales, Maureen Andrew A (1998) meta-analysis of Randomized Controlled Trials. Benefit of heparin in central venous and pulmonary artery catheters 113: 165-171.

9. Pita Birch, Simon Ogden, Michael Hewson (2010) A randomized controlled trial of heparin in total parenteral nutrition to prevent sepsis associated with neonatal long lines: the Heparin in Long Line Total Parenteral Nutrition (HILLTOP) trial 95: F252-257.
10. F Kamala, NY Boo, FC Cheah, K Birinder (2000) Randomized controlled trial of heparin for prevention of blockage of peripherally inserted central catheters in neonates. Acta Paediatr 91: 1350-1356.

11. Bracho-Blanchet E, Cortés-Sauza J, Dávila-Pérez R, LezamaDel Valle P, Villalobos-Alfaro C, et al. (2010) Usefulness of intravenous heparin to prevent thrombosis of central venous catheter in children. Cir 78: 422-428.

12. Shah PS, Kalyn A, Satodia P, Dunn MS, Parvez B, et al. (2007) A randomized, controlled trial of heparin versus placebo infusion to prolong the usability of peripherally placed percutaneous central venous catheters (PCVCs) in neonates: the HIP (Heparin Infusion for PCVC) study. Pediatrics 119: e284-291.

13. Uslu S, Ozdemir H, Comert S, Bolat F, Nuhoglu A, et al. (2010) The effect of low-dose heparin on maintaining peripherally inserted percutaneous central venous catheters in neonates Journal of Perinatology 30: 794-799.
Copyright: (C2020 Muhammad Umar Sahi. This is an open-access article distributed under the terms of the Creative Commons Attribution License, which permits unrestricted use, distribution, and reproduction in any medium, provided the original author and source are credited. 